\title{
Prognostic value of cell-free plasma DNA in patients with cardiac arrest outside the hospital: an observational cohort study
}

\author{
Francisco Arnalich*1, Marta Menéndez¹, Verónica Lagos², Enrique Ciria', Angustias Quesada1', Rosa Codoceo3, \\ Juan José Vazquez', Eduardo López-Collazo ${ }^{4}$ and Carmen Montiel2
}

\begin{abstract}
Introduction: Many approaches have been examined to try to predict patient outcome after cardiopulmonary resuscitation. It has been shown that plasma DNA could predict mortality in critically ill patients but no data are available regarding its clinical value in patients after out-of-hospital cardiac arrest. In this study we investigated whether plasma DNA on arrival at the emergency room may be useful in predicting the outcome of these patients.

Methods: We performed a prospective study of out-of-hospital patients with cardiac arrest who achieved return of spontaneous circulation after successful resuscitation. Cardiovascular co-morbidities and resuscitation history were recorded according to the Utstein Style. The outcome measures were $24 \mathrm{~h}$ and overall in-hospital mortality. Cell-free plasma DNA was measured by real-time quantitative PCR assay for the $\beta$-globin gene in blood samples drawn within two hours after the arrest. Descriptive statistics, multiple logistic regression analysis, and receiver operator characteristic (ROC) curves were calculated.
\end{abstract}

Results: Eighty-five consecutive patients were analyzed with a median time to return of spontaneous circulation of 27 minutes (interquartile range (IQR) 18 to 35). Thirty patients died within $24 \mathrm{~h}$ and 58 died during the hospital course. Plasma DNA concentrations at admission were higher in non-survivors at $24 \mathrm{~h}$ than in survivors (median 5,520 genome equivalents (GE)/ml, vs $2810 \mathrm{GE} / \mathrm{ml}, P<0.01$ ), and were also higher in patients who died in the hospital than in survivors to discharge (median $4,150 \mathrm{GE} / \mathrm{ml}$ vs $2,460 \mathrm{GE} / \mathrm{ml}, P<0.01$ ). Lactate clearance at six hours was significantly higher in 24 h survivors $(P<0.05)$. The area under the ROC curves for plasma DNA to predict 24 -hour mortality and in-hospital mortality were 0.796 ( $95 \%$ confidence interval (Cl) 0.701 to 0.890 ) and 0.652 ( $95 \% \mathrm{Cl} 0.533$ to 0.770 ). The best cut-off value of plasma DNA for $24-\mathrm{h}$ mortality was $4,340 \mathrm{GE} / \mathrm{ml}$ (sensitivity $76 \%$, specificity $83 \%$ ), and for in-hospital mortality was 3,485 GE/ml (sensitivity 63\%, specificity 69\%). Multiple logistic regression analysis showed that the risk of 24-h and of in-hospital mortality increased 1.75-fold and 1.36-fold respectively, for every $500 \mathrm{GE} / \mathrm{ml}$ increase in plasma DNA.

Conclusions: Plasma DNA levels may be a useful biomarker in predicting outcome after out-of hospital cardiac arrest.

\section{Introduction}

Overall survival rate from out-of-hospital cardiac arrest has not increased in parallel with the improvements in cardiopulmonary resuscitation (CPR) $[1,2]$. The hospital discharge rate is $15 \%$ in a meta-analysis that included a total population of over 26,000 patients [3]. Pre-morbid factors, peri-arrest and post-arrest variables [4,5], and several serum

* Correspondence: farnalich.hulp@salud.madrid.org

1 Emergency Medicine Department, Internal Medicine Service, Hospital Universitario La Paz, IDIPaz. Paseo de la Castellana 261. 28046 Madrid, Spain Full list of author information is available at the end of the article markers, for example, two neuroproteins, neuro-specific enolase and S-100 [6,7], serum lactate [8,9], and B-type natriuretic peptide $[10,11]$ have been examined to predict outcome after CPR, although none have proved entirely useful.

The majority of patients who achieve return of spontaneous circulation after successful CPR have a high risk to death in the post-arrest period. A few clinical studies have shown elevated plasma concentrations of soluble adhesion molecules (selectins) [12] and cytokines [13,14] in patients resuscitated from cardiac arrest. This immediate post-resus- 
citation period has some similarities to the sepsis syndrome and septic shock in terms of the inflammatory cascade activation and microcirculatory hypoperfusion [15]. As increased concentrations of cell-free DNA have been found in patients with sepsis and septic shock [16-18], and the plasma DNA concentration is an independent predictor for ICU mortality in these patients [19], we hypothesized that admission DNA concentrations may also predict mortality in patients in the post-cardiac arrest resuscitation period. Therefore, the aim of this study was to evaluate whether cell-free plasma DNA on admission is associated with short-term mortality in patients after out-of-hospital cardiac arrest.

\section{Materials and methods Patients and setting}

Between January 2005 and June 2007, 113 consecutive adult patients who presented to the emergency room after non-traumatic, normothermic, out-of-hospital cardiac arrest were recruited into the study. The inclusion criteria were: 1) age more than 17 years, 2) cardiac arrest prior to the arrival of emergency personnel, 3) pre-arrest GCS $=15$ or independent ADLs, 4) no written do not attempt resuscitation (DNAR) order. Exclusion criteria were: 1) successful resuscitation by bystanders prior to arrival of pre-hospital providers, 2) interval between collapse and the start of CPR longer than 15 minutes, 3 ) no return of spontaneous circulation could be achieved within 60 minutes, 4) survival for less than 12 hours after the event, 5) chronic renal failure treated by hemodialysis, neoplastic diseases, stroke or acute coronary syndrome in the previous 30 days, 6 ) the emergency physician was unable to diagnose their disease, and 7) their families refused to provide informed consent to participate. The study was approved by the local ethics committee. Patient data were collected according to the Utstein Style $[20,21]$ in which cardiac arrest is defined as the absence of palpable pulse and effective spontaneous respiration with initial rhythm ventricular fibrillation (VF), pulseless ventricular tachycardia (PVT), pulseless electrical activity (PEA) and asystole. Resuscitation protocols followed the European Resuscitation Council guidelines [22] and the American Heart Association guidelines [23,24]. Therapeutic hypothermia $\left(33^{\circ} \mathrm{C}\right.$ as the target temperature for $24 \mathrm{~h}$ ) was subsequently performed in comatose survivors whose systolic blood pressure had increased to above $90 \mathrm{~mm} \mathrm{Hg}[25,26]$. The primary endpoint in the study was 24-h mortality. Secondary endpoint was in-hospital mortality.

\section{Blood sampling, processing of plasma and DNA extraction}

After return of spontaneous circulation with standard advanced cardiovascular life support according to the European Resuscitation Council guidelines [22] and the American Heart Association guidelines [23,24], a $10 \mathrm{ml}$ blood sample to measure cell-free plasma DNA was taken from the antecubital vein of each patient immediately after return of spontaneous circulation in the emergency room. Plasma and cells were separated by centrifugation at $1,600 \mathrm{~g}$ $\left(+4^{\circ} \mathrm{C}\right)$ for 10 minutes and plasma samples were stored at $80^{\circ} \mathrm{C}$. Plasma samples were centrifuged at $16,000 \mathrm{~g}$ for 10 minutes before DNA extraction to remove any residual cells. DNA was extracted from $200-\mu$ l plasma samples using the QIAamp DNA Blood Mini Kit (QIAGEN, Hilden, Germany) according to the blood and body fluid protocol recommended by the manufacturer.

\section{Real-time quantitative PCR}

Plasma DNA was measured in duplicate samples by realtime quantitative PCR assay for the $\beta$-globin gene [27] using the ABI PRISM 7000 sequence detection system (Applied Biosystems Inc, Foster City,, CA 94404, USA). PCR primers and the fluorescent probe were designed by Primer Express software (Applied Biosystems). The primer and probe sequences were as follows: forward primer 5'GCA CCT GAC TCC TGA GGA GAA-3', reverse primer 5'-CAC CAA CTT CAT CCA CGT TCA-3', and a singlelabeled fluorescent MGB-probe 5'-FAM-TCT GCC GTT ACT GCC CT-MGB-NFQ, where MGB is a minor groove binding molecule and NFQ a non-fluorescent quencher molecule. Samples were analyzed in duplicate in a reaction volume of $25 \mu \mathrm{l}$ containing $5 \mu \mathrm{l}$ of sample, $300 \mathrm{nM}$ of each primer, $200 \mathrm{nM}$ of probe and $1 \times$ Taqman master mix (Applied Biosystems). PCR cycling conditions were two minutes at $+50^{\circ} \mathrm{C}, 10$ minutes at $+95^{\circ} \mathrm{C}$, and 46 cycles of 20 seconds at $+95^{\circ} \mathrm{C}$ and one minute at $+60^{\circ} \mathrm{C}$. We used a 10 fold serial dilution of human genomic DNA (QIAGEN, Hilden, Germany) as a standard curve. The imprecision of this system has been reported previously (20), with a CV for the threshold cycle of $1.1 \%$. Raw data are converted into units of copies of genomes, and expressed as genome equivalents (GE), per $\mathrm{ml}$ plasma ( $1 \mathrm{GE}=6.6 \mathrm{pg} \mathrm{DNA})$. DNA levels are given to the nearest 25 genome-equivalents $(\mathrm{GE}) / \mathrm{ml}$ and the detection limit is $12.5 \mathrm{GE} / \mathrm{ml}$.

\section{Statistics}

Continuous data are presented as the median and interquartile range. Discrete variables are given as counts and percentages. Lactate clearance at six hours was defined as the difference in initial lactate concentration on arrival at the ED to six hours afterwards divided by initial lactate concentration value and multiplied by 100 . Univariate comparisons of continuous data were performed by MannWhitney $U$-test, and by Chi-square for categorical variables. Non-normal distributions were transformed into normal distributions using a logarithmic transformation. The confidence interval $(95 \% \mathrm{CI})$ was determined as an indication of the precision of an estimate of a population value. The odds ratio (OR) was calculated as an estimate of rela- 
tive risk between two groups on the basis of the mortality as outcome. Multiple logistic regression analysis was used to determine the independent contribution of multiple variables to the outcome of 24-h and in-hospital mortality, and for calculation of adjusted odds ratio. We selected candidate variables for the regression model that were shown to impact mortality in prior studies $[1,2,26]$. A $P<0.01$ level was used for the inclusion of the variables in the model. The discriminative power of DNA and lactate clearance to predict mortality was determined with the use of receiver operator characteristic (ROC) curves. We calculated areas under the curve (AUCs) with $95 \%$ CIs, the best predictive cut-off values and positive likelihood ratios with $95 \%$ CIs according to standard procedures. Statistical significance was set at $P<0.05$ in all tests. The statistical analyses were computed with SPSS 12.0 statistical software (SPSS, Chicago, Ill., USA).

\section{Results}

Overall, 85 patients matched the inclusion criteria for this study. The cause of cardiac arrest was: underlying cardiac disorder $(n=46)$, respiratory failure $(n=30)$, metabolic factors $(n=6)$ and hypovolemia $(n=3)$. Twenty-four-hour mortality and in-hospital mortality were $35.2 \%$ and $65.8 \%$, respectively (Table 1). Patient demography and medical history prior to cardiac arrest, the initial ECG-pattern, and the clinical findings at the time of admission to the emergency room are described in Table 1. Acute myocardial infarction (AMI) was determined as the final diagnosis and cause of cardiac arrest in 48 patients (56.5\%), 35 patients $(72.9 \%)$ had coronary angiography and $25(52.1 \%)$ received percutaneous coronary intervention with stent placement. The main artery occluded was the left anterior descending in 14 patients, the right coronary artery in eight and the circumflex in seven. Four patients had more than one artery involved. Eighteen patients were treated with mild therapeutic hypothermia according to the ALS Task Force of the International Liaison Committee on Resuscitation (25). Initial cold fluid infusions and ice packs combined with external cooling with cold blankets was used to achieve a core temperature of $33^{\circ} \mathrm{C}$ (time to achievement $5.3 \mathrm{~h} \pm 2.1 \mathrm{~h}$ ) and maintained for 24 hours.

The median duration of the ICU stay was 12 days (IQR 5 to 21 ), and the median time until hospital discharge was 36 days (IQR 19 to 47). Clinical characteristics of 24-hour survivors and non-survivors are listed in Table 2. Except for the presence of diabetes, there was no statistical difference with respect to other cardiovascular risk factors or comorbidities. The median cell-free plasma DNA concentration at admission was higher in non-survivors at 24 hours than in survivors $(5,520 \mathrm{GE} / \mathrm{ml}$, vs $2,810 \mathrm{GE} / \mathrm{ml}, P<0.01)$. The plasma DNA concentration was higher in patients with CPR duration longer than 30 minutes than in patients with shorter time of resuscitation $(4,470 \mathrm{GE} / \mathrm{ml}$, vs $3,150 \mathrm{GE} / \mathrm{ml}$,
$P<0.05)$. In addition to plasma DNA, bystander basic life support, total downtime interval (time from collapse until return of spontaneous circulation), asystole as the presenting cardiac rhythm, ongoing CPR on arrival at the emergency room, palpable pulse on arrival at the emergency room, six-hour lactate concentration, six-hour lactate clearance, serum glucose and urea concentrations, and confirmed AMI as final diagnosis were also found to be predictive of 24-hour mortality in a univariate analysis (Table 2). The plasma DNA level at admission was significantly correlated with the total downtime $(\mathrm{r}=0.579, P<$ $0.001)$, maximum lactate concentration $(\mathrm{r}=0.602, P<$ $0.001)$, and the first 24-hour APACHE II score $(\mathrm{r}=0.415, P$ $<0.003$ ). Plasma DNA concentration did not correlate with urea concentration $(\mathrm{r}=0.26, P=0.053)$, nor was it in correlation with age, leukocyte count, troponin, creatinine or glucose.

Plasma DNA concentrations at admission also showed statistical significance regarding the secondary endpoint of inhospital mortality (Table 3). Plasma DNA concentrations were higher in hospital non-survivors than in survivors to discharge (median 4,150 GE/ml vs 2,430 GE/ml, $P<0.01$ ). Asystole as the presenting cardiac rhythm and confirmed AMI as final diagnosis were also found to be statistically significant.

A multivariate analysis by logistic regression to identify factors having independent predictive value for 24-hour mortality and in-hospital mortality was performed. The following variables were entered: 1) age; 2) sex; 3 ) diabetes mellitus; 4) hypertension; 5) coronary artery disease; 6) chronic heart failure; 7) COPD/emphysema; 8) witnessed cardiac arrest; 9) bystander initiated CPR; 10) total downtime interval; 11) asystole as the presenting cardiac rhythm; 12) unconsciousness on arrival at the ER; 13) coma Glasgow scale $<6$ on arrival at the ER; 14) ongoing CPR on arrival at the ER; 15) palpable pulse on arrival at the ER; 15) supraventricular rhythm in the ER; 16) defibrillation in the ER; 17) adrenaline in the ER; 18) cardiogenic shock; 19) confirmed acute myocardial infarction as final diagnosis. Plasma DNA concentrations was the only independent predictor of 24-hour mortality and in-hospital mortality, whereas all other variables were no independently associated with the outcome (Table 4).

ROC curves were calculated for the use of plasma DNA as a predictor of 24-hour and in-hospital mortality and for lactate clearance to predict 24-hour mortality. The area under the ROC curves for plasma DNA to predict 24-hour mortality and in-hospital mortality were 0.796 (95\% CI 0.701 to $0.890)$ and $0.652(95 \%$ CI 0.533 to 0.770$)$ (Figure 1). The area under the ROC curve for six-hour lactate concentration to predict 24-hour mortality was 0.576 (95\% CI, 0.450 to 0.701 ) (Figure 2). The best cut-off value of plasma DNA at admission for 24-hour mortality was $4,340 \mathrm{GE} / \mathrm{ml}$ with a sensitivity of $76 \%$, specificity of $83 \%$, positive likelihood 
Table 1: Descriptive characteristics of the study cohort

\begin{tabular}{|c|c|c|}
\hline Age, years & & 62 (51 to 69$)$ \\
\hline Female & & $38(44.7)$ \\
\hline \multirow[t]{4}{*}{ Cause of cardiac arrest } & Underlying cardiac disorder & $48(56.5)$ \\
\hline & Respiratory failure & $28(32.9)$ \\
\hline & Metabolic factors & $7(8.2)$ \\
\hline & Hypovolemia & $2(2.4)$ \\
\hline \multirow[t]{7}{*}{ Comorbidity } & Previous healthy & $16(18.8)$ \\
\hline & Obesity & $52(61.2)$ \\
\hline & Diabetes & $30(35.3)$ \\
\hline & Hypertension & $48(56.4)$ \\
\hline & Coronary artery disease & $29(34.1)$ \\
\hline & Chronic heart failure & $27(31.7)$ \\
\hline & COPD/emphysema & $24(28.2)$ \\
\hline \multirow[t]{3}{*}{ Initial cardiac rhythm } & Ventricular fibrilation & $19(22.4)$ \\
\hline & Pulseles electrical activity & $21(24.7)$ \\
\hline & Asystole & $45(52.9)$ \\
\hline \multirow[t]{8}{*}{ Resuscitation factors } & "no flow" time & 3 (2 to 6$)$ \\
\hline & "low flow" time & 24 (18 to 34$)$ \\
\hline & Witnessed arrest, n (\%) & $47(55.2)$ \\
\hline & Bystander CPR, n (\%) & $25(29,4)$ \\
\hline & Ongoing CPR & $21(24.7)$ \\
\hline & Glasgow Coma Scale & 6 (4 to 8$)$ \\
\hline & Defibrillation & $40(47.1)$ \\
\hline & Intravenous adrenaline & $67(78.8)$ \\
\hline
\end{tabular}


Table 1: Descriptive characteristics of the study cohort (Continued)

\begin{tabular}{|c|c|c|}
\hline & Adrenaline dose (mg) & $4(2$ to 5$)$ \\
\hline \multirow[t]{8}{*}{ In-hospital diagnosis and treatment } & Head CT & $82(96.4)$ \\
\hline & Thorax CT & $37(43.5)$ \\
\hline & Mild therapeutic hypothermia & $18(21.2)$ \\
\hline & Cardiogenic shock & $16(18.8)$ \\
\hline & Acute myocardial infarction & $48(56.5)$ \\
\hline & Coronary angiography & 35 (72.9\% of the AMI) \\
\hline & Percutaneous coronary intervention & 25 (52.1\% of the AMI) \\
\hline & Intra-aortic balloon pump & $6(7.1)$ \\
\hline \multirow[t]{2}{*}{ Clinical outcome } & 24-h mortality & $30(35.2)$ \\
\hline & In-hospital mortality & $56(65.8)$ \\
\hline \multirow[t]{9}{*}{ Laboratory values } & $\mathrm{pH}$ & 7.14 (7.08 to 7.20$)$ \\
\hline & Basal lactate (mmol/l) & 9.6 (7.0 to 12.7$)$ \\
\hline & 6-h lactate $(\mathrm{mmol} / \mathrm{l})$ & 6.7 (4.8 to 8.0$)$ \\
\hline & 6-h lactate clearance (\%) & 45 (32 to 58$)$ \\
\hline & Bicarbonate $(\mathrm{mmol} / \mathrm{l})$ & $12.8(10.3$ to 17.8$)$ \\
\hline & Glucose (mg/dl) & 210 (175 to 240$)$ \\
\hline & Blood urea nitrogen (mg/dl) & 38 (28 to 52$)$ \\
\hline & Creatinine (mg/dl) & 1.5 (1.1 to 1.8$)$ \\
\hline & Troponin I (ng/dl) & $1.0(0.5$ to 1.4$)$ \\
\hline
\end{tabular}

Data are median (IQR) or number (\%). CT, computed tomography.

ratio of $2.41(95 \% \mathrm{CI}, 2.04$ to 3.26$)$ and correct classification rate of $73 \%$. Regarding the secondary endpoint of inhospital mortality, the best cut-off value of plasma DNA was $3,485 \mathrm{GE} / \mathrm{ml}$ with a sensitivity of $63 \%$, specificity of $69 \%$, positive likelihood ratio of $1.75(95 \%$ CI, 1.44 to 2.35 ) and correct classification rate of $62 \%$. The best cutoff value of six-hour lactate in predicting 24-hour mortality was $7.1 \mathrm{mmol} / 1$, with a sensitivity of $64 \%$, specificity of $61 \%$, positive likelihood ratio of 1.32 (95\% CI, 1.10 to 1.84 ) and correct classification rate of $57 \%$.

\section{Discussion}

A predictive test that would be applicable to comatose patients in the emergency department early after CPR is 
Table 2: Univariate analysis: comparisons of factors associated with 24-h mortality

\begin{tabular}{|c|c|c|c|}
\hline & $\begin{array}{c}\text { Survivors } \\
(\mathrm{n}=55)\end{array}$ & $\begin{array}{l}\text { Non-survivors } \\
(n=30)\end{array}$ & $P$ \\
\hline Age, years & 60 (51 to 69$)$ & 62 (52 to 70 ) & NS \\
\hline Female, & $25(45.4)$ & $13(43.3)$ & NS \\
\hline Hypertension & $30(54.5)$ & $18(60.0)$ & NS \\
\hline Diabetes & $16(29.1)$ & $14(46.6)$ & $<0.05$ \\
\hline Coronary artery disease & $18(32.7)$ & $11(36.6)$ & NS \\
\hline Chronic Heart Failure & $16(29.1)$ & $11(36.6)$ & NS \\
\hline Witnessed arrest & $31(56.4)$ & $16(53.3)$ & NS \\
\hline Bystander CPR & $20(36.4)$ & $5(16.6)$ & $<0.01$ \\
\hline Total downtime & 22 (15 to 29$)$ & $31((22$ to 38$)$ & 0,002 \\
\hline CGS $<6$ on arrival at the ER & $47(85.5)$ & $27(90.0)$ & NS \\
\hline Ongoing CPR on arrival at the ER & $16(29.1)$ & $5(16.7)$ & $<0.05$ \\
\hline Palpable pulse on arrival at the ER & $45(90.9)$ & $19(70.0)$ & $<0.01$ \\
\hline Supraventricular rhythm in the ER & $34(61.8)$ & $20(66.7)$ & NS \\
\hline Asystole & $23(41.8)$ & $22(73.3)$ & 0.002 \\
\hline Defibrillation in the ER & $27(49.1)$ & $13(43.3)$ & NS \\
\hline Adrenaline in the ER & $41(74.5)$ & $26(86.7)$ & NS \\
\hline Cardiogenic shock & $9(16.4)$ & $7(23.3)$ & NS \\
\hline Confirmed AMI as final diagnosis & $34(61.8)$ & $14(46.7)$ & $<0.05$ \\
\hline APACHE II score & 35 (32 to 38$)$ & 38 (33 to 41$)$ & NS \\
\hline Plasma DNA (GE/ml) & $3,970(2,460$ to 4,980$)$ & $5,520(3,870$ to 6,400$)$ & 0.001 \\
\hline Basal lactate $(\mathrm{mmol} / \mathrm{l})$ & 10.7 (9.6 to 12.2$)$ & $11.9(10.7$ to 13.4$)$ & NS \\
\hline 6-h lactate (mmol/l) & 5.7 (4.9 to 6.6$)$ & $8.4(7.1$ to 10.2$)$ & $<0.01$ \\
\hline 6-h lactate clearance (\%) & 55 (47 to 65$)$ & 38 (16 to 57$)$ & $<0.05$ \\
\hline
\end{tabular}


Table 2: Univariate analysis: comparisons of factors associated with 24-h mortality (Continued)

\begin{tabular}{|c|c|c|c|}
\hline Blood sugar (mg/dl) & 214 (180 to 234$)$ & 255 (210 to 275$)$ & $<0.05$ \\
\hline Blood urea nitrogen (mg/dl) & 35 (28 to 41$)$ & 46 (33 to 54$)$ & $<0.05$ \\
\hline
\end{tabular}

needed to help optimize the resuscitative efforts. This is the first prospective clinical study to evaluate the prognostic value of plasma DNA concentration on arrival at the emergency room in patients with out-of-hospital cardiac arrests. Our study shows that high plasma DNA concentration is associated with both 24-hour and in-hospital mortality. A multiple logistic regression analysis showed that raised plasma DNA level was a strong independent predictor of 24-hour mortality and was also independently associated with overall hospital mortality.

The post-resuscitation period after cardiac arrest has been compared to a sepsis-like syndrome, with components of circulatory, cardiogenic, and distributive shock [15]. It has been shown that plasma DNA is a useful independent predictor of mortality and sepsis in intensive care patients $[16,17]$. A prognostic value has also been found in emergency department patients with sepsis [18]. Cell-free plasma DNA measured on admission to the intensive care unit was found to be a predictor of outcome in severe sepsis and septic shock patients included in the Finnsepsis Study Group [19]. As current evidence suggests that the pathophysiology of post-cardiac arrest shock is very similar to that of patients with septic shock, we hypothesized that DNA concentrations at hospital admission might also predict mortality in patients in the immediate post-arrest period. The mechanisms underlying this period probably involve a whole-body ischemia and reperfusion instability that triggers the inflammatory cascade activation similar to that seen in severe sepsis. Plasma DNA is likely to be released from damaged and inflamed tissues, and in this context it might act as a marker of early outcome of patients with hypoxic-ischemic encephalopathy after cardiac arrest. We have demonstrated a role for plasma DNA as an early predictor of mortality in patients after cardiac arrest. Thus, the ability for rapid risk stratification of survival may allow clinicians to make more rational therapeutic decisions. Moderate increases in plasma in plasma DNA may be associated with the chronic inflammatory response to atherosclerotic process which often occurs in elderly patients [28]. In our study there was no difference with respect to cardiovascular risk factors or chronic comorbidities except for diabetes within survivors and non-survivors patients and when entered into the logistic regression model for hospital mortality the adjusted odds ratio was not significant. Therefore it is likely that differences in plasma DNA levels in our study reflect the acute event of cardiac arrest rather than chronic illness.

Tissue hypo-perfusion during the early phase of post-cardiac arrest induces an increase in serum lactate because of anaerobic glycolisis. We have found that cell-free plasma DNA concentration at inclusion correlated significantly with initial lactate concentrations and maximum lactate concentrations within a 24-hour period, which may reflect the effect of tissue hypoxia on apoptotic or necrotic cell death. Effective lactate clearance which likely reflects improved tissue perfusion is associated with decreased mortality in severe sepsis and other critical-care patient populations $[29,30]$. Two studies have reported that postcardiac arrest patients with more effective lactate clearance had improved survival $[7,8]$. Similarly, the current study revealed that lactate clearance at six hours was significantly higher in survivors compared to non-survivors at 24 hours, but we did not find this variable to be an independent predictor for early or late mortality when entered into the multivariable analysis. Further studies are required to establish the independent predictive value of effective lactate clearance after cardiac arrest.

An increase in plasma DNA concentration in critically ill patients may be also due to a decrease in clearance efficiency. The clearance mechanism of DNA from the circulation is poorly understood [31]. In mice, nucleotides are mainly cleared by liver [32]. Approximately 0.5 to $2 \%$ of circulating plasma DNA crosses the kidney barrier and is excreted into urine [33]. We found that serum urea or creatinine were not independently associated with plasma DNA concentrations, which is consistent with data from experimental studies. However, further investigations are required to understand the dynamics of plasma DNA removal in patients with impaired renal and hepatic function. The current study has several methodological limitations. First, it is a single centre study for CPR after out-of-hospital cardiac arrest. Second, the majority of patients had unfavorable peri-arrest variables such as long downtime intervals and pulseless electric activity as presenting arrest rhythms. 
Table 3: Univariate analysis: comparisons of factors associated with in-hospital mortality

\begin{tabular}{|c|c|c|c|}
\hline & $\begin{array}{c}\text { Survivors } \\
(n=29)\end{array}$ & $\begin{array}{l}\text { Non-survivors } \\
(n=56)\end{array}$ & $P$ \\
\hline Age, years & 60 (51 to 69$)$ & 61 (52 to 70$)$ & NS \\
\hline Female & $13(44.8)$ & $25(43.3)$ & NS \\
\hline Hypertension & $15(51.7)$ & $33(58.9)$ & NS \\
\hline Diabetes & $12(41.4)$ & $30(53.6)$ & NS \\
\hline Coronary artery disease & $12(41.4)$ & $27(48.2)$ & NS \\
\hline Chronic heart failure & $9(31.0)$ & $18(32.1)$ & NS \\
\hline Witnessed arrest & $18(62.1)$ & $29(51.8)$ & NS \\
\hline Bystander CPR & $10(16.9)$ & $15(26.8)$ & NS \\
\hline Total downtime, min & 20 (15 to 29 ) & 27 (22 to 35$)$ & NS \\
\hline $\mathrm{CGS}<6$ on arrival at the ER & $24(82.7)$ & $50(89.2)$ & NS \\
\hline Ongoing CPR on arrival at the ER & $7(24.1)$ & $14(25.0)$ & NS \\
\hline Palpable pulse on arrival in the ER & $23(79.3)$ & $48(85.7)$ & NS \\
\hline Supraventricular rhythm in the ER & $17(58.6)$ & $37(66.1)$ & NS \\
\hline Asystole & $11(37.9)$ & $34(60.7)$ & $<0.01$ \\
\hline Defibrillation in the ER & $15(51.7)$ & $25(44.6)$ & NS \\
\hline Adrenaline in the ER & $21(72.4)$ & $46(82.1)$ & NS \\
\hline Cardiogenic shock & $5(17.2)$ & $11(19.6)$ & NS \\
\hline Confirmed AMI as final diagnosis & $19(65.5)$ & $29(51.8)$ & $<0.05$ \\
\hline APACHE II score & 34 (32 to 38$)$ & 37 (33 to 41$)$ & NS \\
\hline Plasma DNA (GE/ml) & $2,400(1,370$ to 3,550$)$ & $4,150(3,460$ to 5,180$)$ & 0.001 \\
\hline Basal lactate $(\mathrm{mmol} / \mathrm{l})$ & $10.8(9.1$ to 12.2$)$ & $11.5(10.3$ to 13.1$)$ & NS \\
\hline 6-h lactate (mmol/l) & 5.5 (4.9 to 6.6$)$ & 6.9 (5.8 to 8.4$)$ & NS \\
\hline 6-h lactate clearance (\%) & 52 (47 to 65$)$ & 43 (27 to 59$)$ & NS \\
\hline
\end{tabular}


Table 3: Univariate analysis: comparisons of factors associated with in-hospital mortality (Continued)

\begin{tabular}{lccc}
\hline Blood sugar (mg/dl) & 195 (165 to 220$)$ & 230 (190 to 245) & NS \\
\cline { 1 - 2 } Blood urea nitrogen $(\mathrm{mg} / \mathrm{dl})$ & $34(28$ to 45$)$ & 40 (33 to 57$)$ & NS \\
\hline
\end{tabular}

Data are median (IQR) or number (\%).

Third, some potential confounders like patient management at the emergency department and intensive care unit are difficult to control. In addition, some pre-analytical factors could have an impact on the results. To avoid contamination of the cell-free circulating plasma DNA measurements by residual white blood cells or platelets we used high-speed centrifugation at $16,000 \mathrm{~g}$ after storage, which almost completely eliminates cellular contamination in these assays. Opposing these limitations, the strengths of this study lie in the prospective design which includes a clearly defined patient sample, and the complete recording of premorbid, peri-arrest and immediate post-arrest variables. In addition, we measured lactate clearance as a marker of severity against which plasma DNA may be compared.

\section{Conclusions}

In conclusion, our study results indicate that plasma DNA measurement on arrival at the emergency room may help physicians to estimate outcome in patients with cardiac arrest outside the hospital. In fact, plasma DNA concentra- tion was a strong independent predictor for 24-hour mortality and was also independently associated with hospital mortality. A large prospective multicenter study is warranted to confirm the role of plasma DNA in outcome prediction after cardiac arrest and to validate the optimal plasma DNA cutoff levels regarding early and late mortality.

\section{Key messages}

- The median plasma DNA concentration on arrival at the emergency department was two-fold higher in nonsurvivors at 24 hours compared to those in survivors following cardiac arrest.

- Plasma DNA concentration was a strong independent predictor for 24-hour mortality and was also independently associated with hospital mortality.

- Plasma DNA measurement on arrival at the emergency room may help physicians to estimate outcome in patients with cardiac arrest outside the hospital.

Table 4: Multiple logistic regression analyses; independent predictors of 24-h and in-hospital mortality

\begin{tabular}{|c|c|c|c|c|c|c|}
\hline & \multicolumn{3}{|c|}{24 -h mortality } & \multicolumn{3}{|c|}{ In-hospital mortality } \\
\hline & Adjusted OR & $95 \% \mathrm{CI}$ & $P$ value & Adjusted OR & $95 \% \mathrm{Cl}$ & $P$ value \\
\hline $\begin{array}{l}\text { Plasma DNA (for each } \\
\text { increase of } 1 \mathrm{GE} / \mathrm{ml} \text { ) }\end{array}$ & 1.001 & 1.001 to 1.002 & $<0.001$ & 1.001 & 1.001 to 1.002 & $<0.001$ \\
\hline $\begin{array}{l}\text { Plasma DNA for each } \\
\text { increase of } 500 \mathrm{GE} / \mathrm{ml} \text { ) }\end{array}$ & 1.756 & 1.314 to 2.347 & $<0.001$ & 1.359 & 1.125 to 2.350 & $<0.01$ \\
\hline $\begin{array}{l}\text { 6-h lactate (for each } \\
\text { increase of } 1 \mathrm{mmol} / \mathrm{l} \text { ) }\end{array}$ & 1.348 & 0.912 to 1.631 & NS & 1.115 & 0.765 to 1.530 & NS \\
\hline $\begin{array}{l}\text { Age (for each increase of } \\
\text { one year) }\end{array}$ & 1.031 & 0.899 to 1.041 & NS & 1.376 & 0.865 to 1.240 & NS \\
\hline $\begin{array}{l}\text { Admission glucose (for } \\
\text { each increase of } 10 \mathrm{mg} / \mathrm{dl} \text { ) }\end{array}$ & 1.019 & 0.833 to 1.282 & NS & 1.012 & $\begin{array}{l}0.780 \text { too } \\
1.320\end{array}$ & NS \\
\hline
\end{tabular}




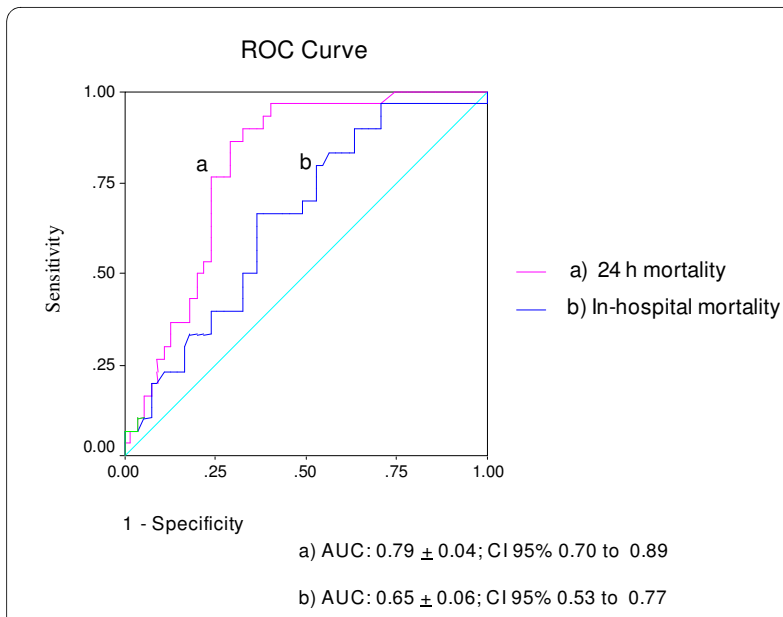

Figure 1 Receiver operating characteristics curve for plasma DNA concentrations and 24-hour and in-hospital mortality. The best cut-off value of plasma DNA for 24-hour mortality was 4,340 GE/ml (sensitivity $76 \%$, specificity $83 \%$ ), and for in-hospital mortality was 3,485 GE/ml (sensitivity 63\%, specificity 69\%).

\section{Abbreviations}

ADL: activities of daily life; CPR: cardiopulmonary resuscitation; COPD/emphy sema: chronic obstructive pulmonary disease/emphysema; ED: emergency department; ER: emergency room; DNAR order: do not attempt resuscitation order; GCS: Glasgow Coma Scale; ICU: intensive care unit; PCR: Polymerase chain reaction; PEA: pulseless electrical activity; PVT: pulseless ventricular tachycardia; VF: ventricular fibrillation.

\section{Competing interests}

The authors declare that they have no competing interests.

\section{ROC Curve}

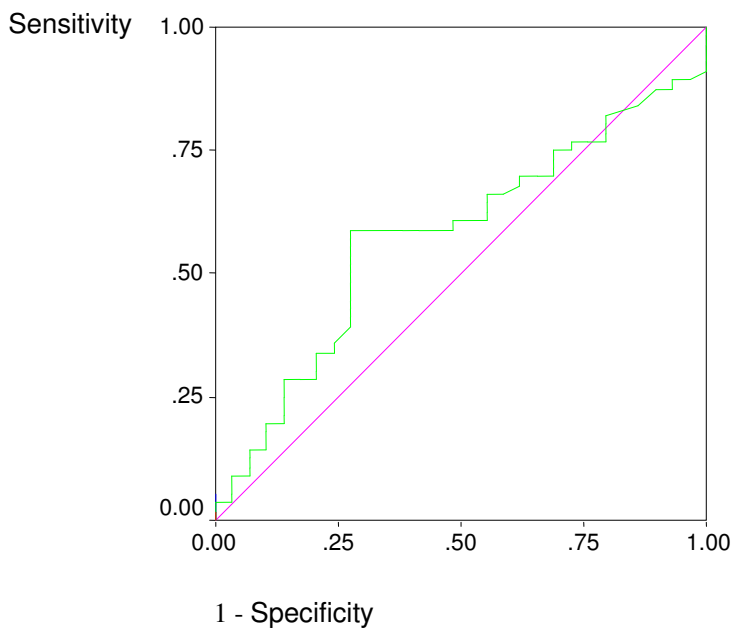

AUC: $0.576 \pm 0.06 ; \mathrm{Cl} 95 \% 0.450$ to 0.701

Figure 2 Receiver operating characteristics curve for six-hour serum lactate concentrations and 24-hour and in-hospital mortality. The best cutoff value of six-hour lactate in predicting 24-hour mortality was $7.1 \mathrm{mmol} / \mathrm{l}$, with a sensitivity of $64 \%$, specificity of $61 \%$.

\section{Authors' contributions}

$F A, M M, E C, A Q$ and VL contributed to acquisition of the data. FA, RC, ELC and CM participated in the study design, coordination and statistical analysis. RC and $\mathrm{CM}$ performed the molecular analysis; FA, ELC and CM drafted the manuscript. All authors read and approved the final manuscript.

\section{Acknowledgements}

We wish to thank Ana Maria de Lucas, and Gema Atienza, for excellent technical assistance, and Rosario Madero for statistical analysis. This work was supported partially by a grant from Plan Nacional I+D+I (SAF 2008-05347) and from Fundación Mutua Madrileña de Investigación Médica to Francisco Arnalich (IP 2007) and to Carmen Montiel (IP 2008).

\section{Author Details}

${ }^{1}$ Emergency Medicine Department, Internal Medicine Service, Hospital Universitario La Paz, IDIPaz. Paseo de la Castellana 261. 28046 Madrid, Spain, 2Department of Pharmacology and Therapeutics, IDIPaz, Facultad de Medicina, Universidad Autónoma de Madrid. Arzobispo Morcillo, 4. 28029 Madrid. Spain, ${ }^{3}$ Clinical Biochemistry Service, Hospital Universitario La Paz, IDIPaz. Paseo de la Castellana 261. 28046 Madrid, Spain and ${ }^{4}$ Medical Research Unit. Hospital Universitario La Paz, IDIPaz Paseo de la Castellana 261. 28046 Madrid, Spain

Received: 19 September 2009 Revised: 17 January 2010

Accepted: 29 March 2010 Published: 29 March 2010

\section{References}

1. Stiell IG, Wells GA, Field B, Spaite DW, Nesbitt LP, De Maio VJ, Nichol G, Cousineau D, Blackburn J, Munkley D, Luinstra-Toohey L, Campeau T, Dagnone E, Lyver M, Ontario Prehospital Advanced Life Support Study Group: Advanced cardiac life support in out-of-hospital cardiac arrest. N Engl J Med 2004, 351:647-656.

2. Fairbanks RJ, Shah MN, Lerner EB, llangovan K, Pennington EC, Schneider SM: Epidemiology and outcomes of out-of-hospital cardiac arrest in Rochester, New York. Resuscitation 2007, 72:415-424

3. Saklayen M, Liss H, Markert R: In-hospital cardiopulmonary resuscitation. Survival in hospital and literature review. Medicine (Baltimore) 1995, 74:163-175.

4. Nolan JP, Laver SR, Welch CA, Harrison DA, Gupta V, Rowan K: Outcome following admission to UK intensive care units after cardiac arrest: a secondary analysis of the ICNARC Case Mix Programme Database. Anaesthesia 2007, 62:1207-1216.

5. Kaye P: Early prediction of individual outcome following cardiopulmonary resuscitation: systematic review. Emerg Med J 2005, 22:700-705

6. Pfeifer R, Börner A, Ktack A, Sigusch HH, Surber R, Figulla HR: Outcome after cardiac arrest: predictive values and limitations of the neuroproteins neuron-specific enolase and protein S-100 and the Glasgow Coma Scale. Resuscitation 2005, 65:49-55.

7. Rech TH, Rios Vieira SR, Nagel F, Salles Brauner J, Scalco R: Serum neuronspecific enolase as early predictor of outcome after in-hospital cardiac arrest: a cohort study. Crit Care 2006, 10:R133.

8. Kliegel A, Losert H, Sterz F, Holzer M, Zeiner A, Havel C, Laggner AN: Serial lactate determinations for prediction of outcome after cardiac arrest. Medicine (Baltimore) 2004, 83:274-279.

9. Donnino MW, Miller J, Goyal N, Loomba M, Sankey SS, Dolcourt B, Sherwin R, Otero R, Wira C: Effective lactate clearance is associated with improved outcome in post-cardiac arrest patients. Resuscitation 2007, 75:229-234

10. Nagao K, Hayashi N, Kanmatsuse K, Kikuchi S, Kikushima K, Watanabe K, Mukouyama T: B-type natriuretic peptide as a marker of resuscitation in patients with cardiac arrest outside the hospital. Circ J 2004, 68:477-482

11. Sodeck GH, Domanovits H, Sterz F, Schillinger M, Losert H, Havel C, Kliegel A, Vlcek M, Frossard M, Laggner AN: Can brain natriuretic peptide predict outcome after cardiac arrest? An observational study. Resuscitation 2007, 74:439-445.

12. Geppert A, Zorn G, Karth GD, Haumer M, Gwechenberger M, KollerStrametz J, Heinz G, Huber K, Siostrzonek P: Soluble selectins and the systemic inflammatory response syndrome after successful cardiopulmonary resuscitation. Crit Care Med 2000, 28:2360-2365. 
13. Shyu KG, Chang H, Lin CC, Huang FY, Hung CR: Concentrations of serum interleukin-8 after successful cardiopulmonary resuscitation in patients with cardiopulmonary arrests. Am Heart J 1997, 134:551-556.

14. Adrie C, Adib-Conquy M, Laurent I, Monchi M, Vinsonneau C, Fitting C, Fraisse F, Dinh-Xuan T, Carli P, Spaulding C, Dhainaut JF, Cavaillon JM: Successful cardiopulmonary resuscitation after cardiac arrest as a "sepsis-like" syndrome. Circulation 2002, 106:562-568.

15. Adrie C, Laurent I, Monchi M, Cariou A, Dhainaut JF, Spaulding C: Postresuscitation disease after cardiac arrest: a sepsis-like syndrome? Curr Opin Crit Care 2004, 10:208-212.

16. Rhodes A, Wort SJ, Thomas H, Collinson P, Bennett ED: Plasma DNA concentration as predictor of mortality and sepsis in critically ill patients. Crit Care 2006, 10:R60.

17. Saukkonen K, Lakkisto P, Varpula M, Varpula T, Voipio-Pulkki L-M, Pettilä V, Pulkki K: Association of cell-free plasma DNA with hospital mortality and organ dysfunction in intensive care patients. Intensive Care Med 2007, 33:1624-1627.

18. Arnalich F, Codoceo R, López-Collazo E, Montiel C: Plasma DNA is outcome predictor in emergency department patients with sepsis [abstract]. Intensive Care Med 2007, 33:S94.

19. Saukkonen K, Lakkisto P, Pettilä V, Varpula M, Karlsson S, Ruokonen E, Pulkki K: Cell-free plasma DNA as a predictor of outcome in severe sepsis and septic shock. Clin Chem 2008, 54:1000-1007.

20. Jacobs I, Nadkarni V, Bahr J, Berg RA, Billi JE, Bossaert L, Cassan P, Coovadia A, D'Este K, Finn J, Halperin H, Handley A, Herlitz J, Hickey R, Idris A, Kloeck W, Larkin GL, Mancini ME, Mason P, Mears G, Monsieurs K, Montgomery W, Morley P, Nichol G, Nolan J, Okada K, Perlman J, Shuster M, Steen PA, Sterz F, et al: Cardiac arrest and cardiopulmonary resuscitation outcome reports: update and simplification of the Utstein templates for resuscitation registries. A statement for healthcare professionals from a task force of the International Liaison Committee on Resuscitation (American Heart Association, European Resuscitation Council, Australian Resuscitation Council, New Zealand Resuscitation Council, Heart and Stroke Foundation of Canada, Inter American Heart Foundation, Resuscitation Council of Southern Africa). Circulation 2004, 110:3385-3397.

21. Langhelle A, Nolan J, Herlitz J, Castren M, Wenzel V, Soreide E, Engdahl J, Steen PA: Recommended guidelines for reviewing, reporting, and conducting research on post-resuscitation care: the Utstein style. Resuscitation 2005, 66:271-283.

22. Nolan JP, Deakin CD, Soar J, Bottiger BW, Smith G: European Resuscitation Council guidelines for resuscitation 2005. Section 4. Adult advanced life support. Resuscitation 2005, 67(suppl):S39-86.

23. 2005 American Heart Association Guidelines for Cardiopulmonary Resuscitation and Emergency Cardiovascular Care: Part 7.2. Management of cardiac arrest. Circulation 2005, 112(suppl): IV-58-66

24. 2005 American Heart Association Guidelines for Cardiopulmonary Resuscitation and Emergency Cardiovascular Care: Part 7.5. Post Resuscitation Support. Circulation 2005, 112(suppl): IV-84-88

25. Nolan JP, Morley PT, Hoek TL, Hickey RW: Therapeutic hypothermia after cardiac arrest. An advisory statement by the Advancement Life Support Task Force of the International Liaison Committee on Resuscitation. Resuscitation 2003, 57:231-235

26. Nolan JP, Neumar RW, Adrie C, Aibiki M, Berg RA, Böttiger BW, Callaway C, Clark RSB, Geocadin RG, Jauch EC, Kern KB, Laurent I, Longstreth WT, Merchant RM, Morley P, Morrison LJ, Nadkarni V, Peberdy MA, Rivers EP, Rodriguez-Nunez A, Sellke FW, Spaulding C, Sunde K, Vanden T, Hoek TV: Post-cardiac arrest syndrome: Epidemiology, pathophysiology, treatment, and prognostication. A Scientific Statement from the International Liaison Committee on Resuscitation; the American Heart Association Emergency Cardiovascular Care Committee; the Council on Cardiovascular Surgery and Anesthesia; the Council on ardiopulmonary, Perioperative, and Critical Care; the Council on Clinical Cardiology; the Council on Stroke. Resuscitation 2008 79:350-379

27. Lo YMD, Tein MSC, Lau TK, Haines CJ, Leung TN, Poon PMK, Wainscoat JS, Johnson PJ, Chang AM, Hjelm NM: Quantitative analysis of fetal DNA in maternal plasma and serum: implications for noninvasive prenatal diagnosis. Am J Hum Genet 1998, 62:768-775.

28. Fournie GJ, Martres F, Porrat JP, Alary C, Rumeau M: Plasma DNA as cell death marker in elderly patients. Gerontology 1993, 39:215-221.
29. Bakker J, Gris P, Coffernils M, Kahn RJ, Vincent JL: Serial blood lactate levels can predict the development of multiple organ failure following septic shock. Am J Surg 1996, 171:221-226.

30. Marecaux G, Pinsky MR, Dupont E, Kahn RJ, Vincent JL: Blood lactate levels are better prognostic indicators than TNF and IL-6 levels in patients with septic shock. Intensive Care Med 1996, 22:404-408.

31. Vaart M van der, Pretorius PJ: Circulating DNA. Its origin and fluctuation. Ann N Y Acad Sci 2008, 1137:18-26.

32. Gauntier VJ, Tyler LN, Mannik M: Blood clearance kinetics and liver uptake of mononucleosomes in mice. J Immunol 1996, 156:1151-1156.

33. Botezatu I, Serdyuk O, Potapova G, Shelepov V, Alechina R, Molyaka Y, Ananév V, Bazin I, Garin A, Narimanov M, Knysh V, Melkonyan H, Umansky S, Lichtenstein A: Genetic analysis of DNA excreted in urine: a new approach for detecting specific genomic DNA sequences from cells dying in an organism. Clin Chem 2000, 46:1078-1084.

doi: $10.1186 /$ cc8934

Cite this article as: Arnalich et al., Prognostic value of cell-free plasma DNA in patients with cardiac arrest outside the hospital: an observational cohort study Critical Care 2010, 14:R47

\section{Submit your next manuscript to BioMed Central and take full advantage of:}

- Convenient online submission

- Thorough peer review

- No space constraints or color figure charges

- Immediate publication on acceptance

- Inclusion in PubMed, CAS, Scopus and Google Scholar

- Research which is freely available for redistribution

Submit your manuscript at www.biomedcentral.com/submit
C) Biomed Central 